\title{
Identification of SNP rs1799854 ABCC8 gene and blood glucose levels in patients with type 2 diabetes mellitus at Moewardi hospital Surakarta Solo
}

\author{
Mardiana Puji Lestari ${ }^{1}$, Imaniar Noor Faridah ${ }^{*}{ }^{2}$, Rita Maliza ${ }^{3}$, Haafizah Dania ${ }^{2}$, \\ Melinda Widianingrum ${ }^{3}$, Dyah Aryani Perwitasari ${ }^{1,2}$ \\ ${ }^{I}$ Postgraduate Program on Clinical Pharmacy, Faculty of Pharmacy Universitas Ahmad Dahlan, \\ Jl. Prof. Dr. Soepomo,S.H, Warungboto, Umbulharjo, Yogyakarta, Indonesia \\ ${ }^{2}$ Faculty of Pharmacy Universitas Ahmad Dahlan, \\ Jl. Prof. Dr. Soepomo,S.H, Warungboto, Umbulharjo, Yogyakarta, Indonesia \\ ${ }^{3}$ Biology Study Program, Faculty of Applied Science and Technology Universitas Ahmad Dahlan, \\ Jl. Jend. Ahmad Yani, Tamanan, Banguntapan, Bantul, Yogyakarta, Indonesia
}

Accepted: 03-08-2021

\begin{abstract}
Type 2 diabetes mellitus (T2DM) is a complex metabolic disease characterized by high blood glucose levels due to impaired insulin secretion or insulin resistance. Polymorphisms in the $A B C C 8$ gene rs1799854 are widely found to have an association with T2DM, where the $A B C C 8$ gene encodes the SUR1 protein from the K-ATP channel that plays a role in insulin secretion in cells $\beta$ pancreas. Mutations in the $A B C C 8$ gene can cause potassium channels and insulin secretions problems that possibly decrease the effectiveness of the drug. Polymorphisms in some populations have been reported, but similar research on Solo's population has never been conducted. The purpose of this study is to identify the genotype of the $A B C C 8$ gene in rs1799854 and the therapeutic outcome of blood glucose levels in T2DM patients. This research is cross-sectional research conducted prospectively at Moewardi Hospital Surakarta, Solo. Blood samples were collected from 10 T2DM patients who received sulfonylurea monotherapy taken through veins for genotype examination by DNA isolation, PCR amplification, and sequencing. Parameters of fasting blood glucose (FBG), 2hour postprandial blood glucose, and HbA1c are measured as therapeutic outcomes. We found the dominant results in a mutant homozygote (TT) $40 \%$; while wild type (CC); and a mutant heterozygote (CT) was 30\%. Single Nucleotide Polymorphisms (SNP) of ABCC8 gene rs1799854, found in T2DM patients at Moewardi Hospital Surakarta, Solo, who received sulfonylurea therapy.
\end{abstract}

Keywords: T2DM, Sulfonylurea, $A B C C 8$ gene, Outcome therapy, SNP

\footnotetext{
*Corresponding author:

Imaniar Noor Faridah

Faculty of Pharmacy, Universitas Ahmad Dahlan

J1. Prof. Dr. Soepomo,S.H, Warungboto, Umbulharjo, Yogyakarta, Indonesia

Email: imaniar.faridah@pharm.uad.ac.id
} 


\section{INTRODUCTION}

Type 2 diabetes mellitus (T2DM) is a complex metabolic disease characterized by high blood glucose levels due to impaired insulin secretion and, or insulin resistance (Engwa et al., 2018). Diabetes is a health problem which the number of cases and prevalence continues to increase. WHO estimates that globally 422 million people over the age of 18 lived with diabetes in 2014 (Kemenkes, 2018), it became a global health problem affecting more than 150 million patients worldwide (Koren and Koren, 2015). Based on Basic Health Research (Riskesdas, 2018), Central Java is the $12^{\text {th }}$ largest diabetes mellitus patient in Indonesia (Riskesdas, 2018). The prevalence of type 2 DM in Central Java is 67.977 people, and for the city of Surakarta (Solo), the prevalence is 3.73\% which is the highest percentage in Central Java (Kemenkes RI, 2018). The previous research on Surakarta Health Office data told that the prevalence of type $2 \mathrm{DM}$; has changed in the last five years. A total of 5223 cases of DM; in 2016, then increased to 6.579 points in 2017. The highest prevalence was reported in the Serengan subdistrict (14.38 in 1,000 inhabitants) (Januaristiningtyas, 2018).

Sulfonylurea (SU); is widely used in treating T2DM with the mechanism of increasing insulin secretion (Klen et al., 2014). Insulin secretion is controlled by the sensitive ATP potassium channel $\left(\mathrm{K}_{\mathrm{ATP}}\right)$. The track consists of four Kir6.2 forming subunits along with four sulfonylurea receptor subunits (SUR). SUR1 is a potassium channel sensitive to ATP in pancreatic beta cells (Venkatesan et al., 2014), and is encoded by the ATP Binding Cassette Subfamily C Member 8 (ABCC8) gene (Engwa et al., 2018). The mechanism of insulin release in $\beta$ pancreatic cells starts when glucose entering the cells and resulting ATP that can bind to the $K_{\text {ATP }}$ channel. $K_{\text {ATP }}$ channel will close and cause membrane depolarization resulting in the opening of Voltage-Dependent Calcium Channel (VDCC), pumping $\mathrm{Ca}^{2+}$ into the cell and triggering the secretion of insulin granules (Wiyatno et al., 2011).

The $A B C C 8$ gene encodes a protein that includes a member of the superfamily of ATP-binding cassette (ABC) transporters (Anonim, 2021). SUR1, which is encoded by the $A B C C 8$ gene located on chromosome 11p15, is one of the causes of T2DM risk (Venkatesan et al., 2014). The ABCC8 gene, as a sulfonylurea receptor, helps regulate insulin by coding the SUR1 subunit protein from the K-ATP channel that plays a role in insulin secretion from pancreatic $\beta$ cells. Abnormal SUR1 (ABCC8) can disrupt the potassium channel and insulin secretion (Zhou et al., 2019). Several polymorphism studies have been conducted in the ABCC8 gene, C49620T (rs1799854) in the Nigerian population (Engwa et al., 2018) and rs1801261 in Danish and Canadian people, were known associated with the risk of T2DM. However, four previous studies showed that polymorphism ABCC8 gene rs1801261 was not associated with T2DM risk (Zhou et al., 2019). Polymorphism in rs757110 indicates similar T2DM risk in Europe and Japan, but no association was observed in the Han Chinese population (Qin et al., 2013). Another result in the South India population showed that the polymorphism $A B C C 8$ gene rs1799854 $(-3 \mathrm{c} \rightarrow \mathrm{t}$ ) has no relationship with T2DM (Venkatesan et al., 2014). Research on the ABCC8 gene in T2DM patients in the Solo population has never been reported. Moreover, the purpose of this study is to find out the description of the $A B C C 8$ gene genotype and blood glucose levels as an outcome therapy in T2DM patients who use sulfonylurea.

\section{MATERIALS AND METHOD \\ Research subjects}

The study subjects were all outpatients diagnosed with T2DM at Moewardi Hospital Surakarta, Solo from September 1 to October 30, 2019, who met the inclusion criteria ,i.e. > 18 years old, have complete data of T2DM treatment have complete data of T2DM treatment in medication records, use sulfonylurea monotherapy, and willing to follow this research. Patients were pregnant and using insulin monotherapy or other combinations of oral anti-diabetic therapy were excluded from the study. Blood samples taken through veins as much as $3 \mathrm{ml}$ are inserted in the EDTA tube and stored at a temperature of $-20^{\circ} \mathrm{C}$. 


\section{Materials}

The materials of this study are blood samples derived from T2DM patients, proteinase $\mathrm{K}$, ethanol 96\%, Favorprep kit (Favorgen Biotech, Taiwan), Genomic DNA mini Kit, collection tube, sterile microcentrifuge tube, spin columns. Materials for DNA amplification with PCR are pure DNA samples, PCR master Mix: Go tag green (Promega, USA), $\mathrm{ddH}_{2} \mathrm{O} / \mathrm{Nuclease-Free} \mathrm{water} \mathrm{(Promega,}$ USA), and primary forward $A B C C 8$ and reverse primary $A B C C 8$ (Macrogen, Korea). Materials for electrophoresis and gel visualization are agarose powder (Promega, USA), GelRed/staining gel (Promega, USA), ladder (Geneaid, Taiwan), loading dye (Geneaid, Taiwan), buffer TAE 0.5x, and TAE 1x (Promega, USA).

\section{Methods}

This research is cross-sectional research with future data retrieval. Approval of the ethics committee of this research was obtained from Ahmad Dahlan University No. 011904040, which has been approved by the ethics committee of Moewardi Hospital Surakarta. Informed consent was obtained from all patients before this study.

DNA is isolated and purified from $200 \mu \mathrm{l}$ of whole blood samples using the FavorPrep Kit method $^{\mathrm{TM}}$, and DNA extraction protocols are carried out by following manufacture instructions. Purified DNA is qualitatively tested with electrophoresis to observe the presence of the DNA band. The concentration and purity of DNA are carried out with spectrophotometry. Amplification of the $A B C C 8$ gene was performed using polymerase chain reaction (PCR), which specific primer forward: 5'-TTGGGTGCATCTGTCTGTCTGTCTTT-3' and Reverse 5'-AGCCCACCTGCCCCACGAT-3' (Engwa et al., 2018). The volume of PCR product was $25 \mu$ consisting of a master mix of $12.5 \mu \mathrm{l}$ Go tag green, $\mathrm{ddH}_{2} \mathrm{O} 9.5 \mu \mathrm{l}$, one $\mu \mathrm{l}$ primary forward and one $\mu \mathrm{l}$ reverse primer and one $\mu \mathrm{l}$ DNA template. PCR is carried out with the protocol: initial denaturation at $94{ }^{\circ} \mathrm{C}$ for 5 minutes, denaturation at $94{ }^{\circ} \mathrm{C}$ for 30 seconds, annealing at $60.5^{\circ} \mathrm{C}$ for 30 seconds, extension at $72^{\circ} \mathrm{C}$ for 40 seconds, and a final extension at $72^{\circ} \mathrm{C}$ for 4 minutes. PCR products in electrophoresis with a master mix of $5 \mu$ PCR DNA samples plus five $\mu$ l staining gel/GelRed (DNA dye) and six $\mu$ ladder, the solution is inserted in the gel well agarose $2 \%$ and running at 80 Volts for 80 minutes in a solution buffer TAE $1 \mathrm{x}$. The observation was done with GelDoc (BLuPAD) at $122 \mathrm{bp}$ and then, followed by the sequencing method.

DNA sequencing was identified by the sanger-sequencing method. PCR products are assessed for sequencing tests. The sequencing (forward and reverse) data obtained was trimmed with the SnapGene program. Furthermore, genotypes were analyzed with the help of BioEdit software. When the sequencing data was obtained, the sequence forward and reverse merged (contig) then made a consensus. The consensus data was aligned on the NCBI data bank (http://blast.ncbi.nlm.nih.gov/Blast.cgi). The reference/library of $A B C C 8$ genes on the NCBI website is a reference for normal genes in detecting the point of mutation. The consensus of 10 samples was collected and aligned with the connection using the CLUSTALW approach that integrated into, with Bioedit program, identification of mutation diversity, observe suitability with electropherogram.

\section{Data Description}

The demographic characteristics of the patient describe descriptively include age, gender, ethnicity, education, occupation, therapeutic outcome (Fasting blood glucose (FBG), 2-hour postprandial blood glucose, and Hemoglobin A1c (HbA1c) levels), genotype, and allele frequency.

\section{RESULT AND DISCUSSION}

Demographic characteristics of patients

Several 100 T2DM patients at Moewardi Hospital Surakarta were recruited for this study;ten patients who received sulfonylurea monotherapy were classified as research subjects, while the remaining 90 patients used a combination of a biguanide and sulfonylurea therapy. Demographic 
characteristics of $10 \mathrm{~T} 2 \mathrm{DM}$ patients showed the same gender, with an average age of $69.20 \pm 8.9$ years, ranging from 58-80 years old. According to previous research data, T2DM increases related to age (Firdaushty et al.,2020), and the most extensive DM; sufferers are in the age range of 55-74 years which means that the age factor is substantial on the risk of DM; (Kemenkes, 2018). Patients who have higher education ( $>$ senior high school) were about $20 \%$ and employed $(80 \%)$. Characteristic patients in this study are similar to the previous research that most diabetes mellitus patients are workers (private or government employees) and those at age more than 40 years old (Al Mansour, 2020). A population-based study in China reported that risk factor of diabetes mellitus includes geriatic patients, lower educational level, and having comorbidities (Hu et al., 2017). The average level of FBG was 219 $\mathrm{mg} / \mathrm{dl}$, 2-hour postprandial blood glucose was $176.40 \mathrm{mg} / \mathrm{dl}$, and the value of HbA1c groups was 8.06 $\%$ (Table 1). The mean of DNA concentrations in all samples was $210 \mathrm{ng} / \mu \mathrm{l}$ with a purity index of 1.5 to 2.3 .

Table 1. Demographic characteristics of patients who received sulfonylurea monotherapy $(\mathbf{n}=10)$

\begin{tabular}{clll}
\hline Characteristics & \multicolumn{1}{c}{ Respondents } & N $(\%)$ & Average \pm SD \\
\hline Gender & Male & $5(50 \%)$ & \\
& Female & $5(50 \%)$ & \\
Education & S Senior High School (SD, $8(80 \%)$ & \\
& SMP) & & \\
& Denior High School (SMA, $2(20 \%)$ & \\
D1/2/3, S1/2/3) & & \\
Occupation & Employed & $8(80 \%)$ & $69.20 \pm 8.9$ \\
Age & Unemployed & $2(20 \%)$ & $219.0 \pm 111.58$ \\
FBG & & & $176.40 \pm 132.06$ \\
2-hour postprandial & & & \\
blood glucose & & & \\
HbA1c & & & \\
Medication & Glibenclamide 5mg & $1(10 \%)$ & \\
& Glimepiride & $2(20 \%)$ & \\
& Gliquidone 30mg & $4(40 \%)$ & \\
& Gliclazide & $3(30 \%)$ & \\
& &
\end{tabular}

Notes: SD; Primary School, SMP Junior High School, SMA Senior High School, Diploma 1/2/3, S1/2/3: Bachelor 1/2/3; FBG: Fasting Blood Glucose, HbA1C Hemoglobin A1c

\section{Genotype analysis of $A B C C 8$ rs1799854}

Insulin secretion and insulin retention related to genetic and environmental factors are the most common causes of T2DM (Begic et al., 2016). This current study was conducted to identify the SNP rs1799854 ABCC8 gene and blood glucose levels of T2DM patients who use sulphonylurea. One treatment in T2DM is sulfonylurea which can decrease blood glucose levels by increasing insulin secretion (Gumantara and Oktarlina, 2017). Sulfonylurea will bind to sulfonylurea receptors (SUR) to regulate of insulin secretion from pancreatic beta cells encoded by the $A B C C 8$ gene (Venkatesan et al., 2014).

Sulfonylurea is a second-line anti-diabetic that is used if the goal of first-line therapy (metformin) for three months, which is a decrease in HbA1c levels less than $7.5 \%$, is not achieved 
(ADA, 2020). However, in 10 patients who consume sulfonylurea therapy, HbA1c levels remained > 7.5\%. There are other factors that affect HbAlc levels remain high, includes adherence to taking medication or genetic factors due to variations in the $A B C C 8$ gene, significantly it will disrupt the potassium channel and insulin regulation that causes the patient's blood glucose levels to become uncontrolled (Zhou et al., 2019). The quality of DNA tested with electrophoresis method, and quantitative using spectrophotometry. The ten samples have amplified by using PCR with a specific primer for the $A B C C 8$ gene. The amplification results were identified by using electrophoresis with $2 \%$ gel agarose and then observed with GelDoc at 122 bp (Figure 1).

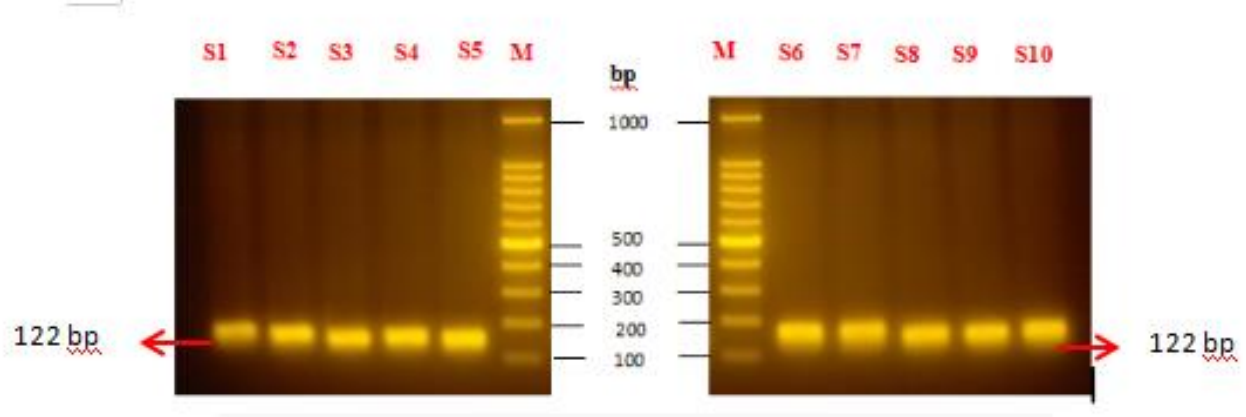

Figure 1. Amplification of $A B C C 8$ gene PCR products at $122 \mathrm{bp}(\mathrm{M}=\mathrm{DNA}$ marker $100 \mathrm{bp})$

Sequencing data were analyzed using SnapGene (to perform electropherogram trimming/cleaning with quality below 40) and Bioedit to see the mutation point. The target gene must match with the bank's genes, a consensus that has been collected blasted on the NCBI website (http://blast.ncbi.nlm.nih.gov/Blast.cgi). The results of genotype analysis of the ABCC8 gene with BioEdit (Figure 2) showed mutant homozygote points in samples no. 1, 4, 8, and 10 and mutant heterozygote in samples 2, 3, and 7 of the standard reference that is $\mathrm{C}$ allele changed to $\mathrm{T}$.

(A)

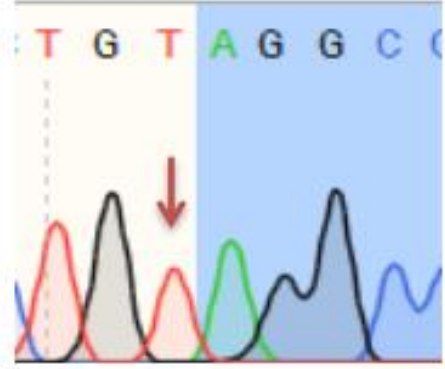

(B)

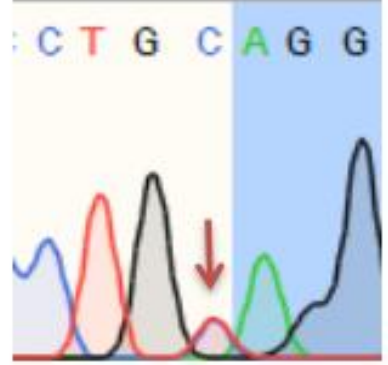

(C)

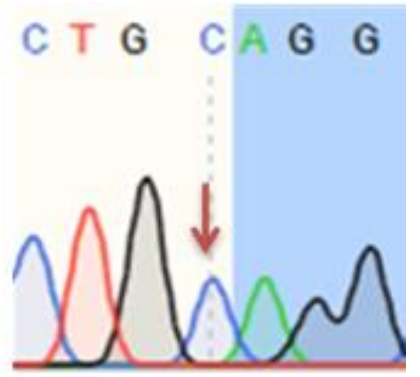

Figure 2. An image of Electropherogram sequencing a point mutation in the $A B C C 8$ gene. $A=$ samples 1,4, 8, and 10 mutant homozygote mutation $(C C \rightarrow T T), B=$ samples 2,3 , and 7 mutant heterozygote mutation $(\mathrm{CC} \rightarrow \mathrm{CT}) \mathrm{C}=$ sample 5,6, and 9 wild-type $(\mathrm{CC})$

Genotype analysis of $A B C C 8$ gene variations with PCR-sequencing method in 10 samples was amplified with $A B C C 8$ target gene at $122 \mathrm{bp}$ and obtained the percentage of $\mathrm{T}$ allele was greater than $\mathrm{C}$ allele in T2DM patients in Solo population. The distribution of CC (homozygote wild-type); and CT; (mutant heterozygote) genotypes has the same percentage, in contrast, the TT; genotype distribution (mutant homozygote) showed dominant in T2DM patients in the Solo population. The 
dominance of TT; genotype (mutant homozygote) is comparable to the increasing prevalence of T2DM in Solo (Table 2).

Table 2. Genotype and allele frequencies of the rs1799854 $A B C C 8$ gene

\begin{tabular}{lc}
\hline & Patients (N=10) \\
\hline Genotype & $3(30 \%)$ \\
CC & $3(30 \%)$ \\
CT & $4(40 \%)$ \\
TT & \\
Allele & $0.45(45 \%)$ \\
C & $0.55(55 \%)$ \\
T
\end{tabular}

The results of genotype sequencing analysis in this study showed that the distribution of genotype TT; (mutant homozygote) and mutant T allele frequency present a dominant percentage. Previous research demonstrated that $A B C C 8$ gene polymorphism encodes SUR1 has been studied with many variants, including C49620T (rs1799854). It was related to T2DM in the Nigerian population, showing the dominant of $\mathrm{T}$ allele over $\mathrm{C}$ allele with a significant risk in T2DM ( $\mathrm{p}<0.05$ ) (Engwa et al., 2018). However, different findings from other regions worldwide showed wild-type; $\mathrm{C}$ allele is usually more dominant in the population. Mutant homozygote TT; genotypes appear more frequently than wild-type; $\mathrm{CC}$ genotypes whereas CT; heterozygote is rarest. Genotype TT is more common in T2DM patients than normal individuals (Engwa et al., 2018). Similar results with this study, where the most dominant genotype of TT; often appears, which $40 \%$ compared to $\mathrm{CC}$ and $\mathrm{CT}$; genotypes. In comparison the dominant frequency of the $\mathrm{T}$ allele is $55 \%$.

This study found a variation point in the $A B C C 8$ gene rs 1799854 , wherein the previous study, there were three polymorphisms of the $A B C C 8$ gene related to sulfonylurea response, namely rs757110, rs1799854, and rs1799859. Polymorphism missense at rs757110 in the ABCC8 SUR-1 gene appears to have a higher likelihood of responding to sulfonylurea treatment (Ordelheide et al., 2018). Most of the research on T2DM related to variation in the ABCC8 gene focused on rs757110, rs1799854, rs1799859, and rs1801261. The $A B C C 8$ gene polymorphism at rs757110 is located at the exons, where there is a change from base $\mathrm{G}$ to $\mathrm{T}$ (GCC $\rightarrow$ TCC), which converts amino acids from alanine in residues 1369 into serine (Ala1369Ser) (Haghverdizadeh et al., 2014). Another polymorphism, rs 1799854, is located in the intron 15 exon 16-3c/t. About 17 studies on Asian and Caucasian populations (Sakamoto et al., 2007) proved this polymorphism, and six studies reported a link between this variation and the risk of T2DM and Gestational DM; in the populations of Japan (Yokoi et al., 2006), China, France, Turkey, and the Netherlands. For CT, genotype carriers in Japan and Turkey are more sensitive to the risk of T2DM, and in genotypes, TT; is more common inpatient populations in China and France. Meanwhile, CC genotypes are at higher risk in T2DM patients in Chinese and Dutch people (Zhou et al., 2009) (Haghverdizadeh et al., 2014). Polymorphism of rs1799859 is located in the exons area, which there is a substitution from $\mathrm{G}$ allele to A allele (AGG $\rightarrow$ AGA), However, it did not make any changes (Haghverdizadeh et al., 2014). While polymorphism of rs1801261 is located in the exons area, where the SNP converts the $\mathrm{C}$ allele into the T allele (ACC $\rightarrow$ ACT), but does not cause changes in amino acid threonine in residue 759 (Thr759Thr) (Venkatesan et al., 2014) (Haghverdizadeh et al., 2014).

\section{Genotype distribution and outcome therapy}

In patients with $A B C C 8$ gene variations rs1799854, the therapeutic outcomes (FBG, 2-hour postprandial blood glucose, and HbA1c levels) were uncontrolled. However, in this study, patients with wild-type; genotypes also presented uncontrolled therapeutic outcomes. The outcomes defined as controlled if FBG <126 mg/dl, 2-hour postprandial blood glucose $<200 \mathrm{mg} / \mathrm{dl}$, HbA1c levels $<6,5 \%$. 
However the outcomes becomes uncontrolled if FBG $>126 \mathrm{mg} / \mathrm{dl}$, 2-hour postprandial blood glucose $>200 \mathrm{mg} / \mathrm{dl}$, HbA1c levels $>6,5 \%$ (Table 3 ). This can be caused by many factors, such as genetic factors, environmental factors (lifestyle), compliance with medications as well as the right combination of treatments. According to previous research, the combination of metformin and sulfonylurea was declared more effective in controlling blood glucose levels. Moreover, other research conducted in China reported the effectiveness of a combination of therapies between glibenclamide and metformin in T2DM patients compared to glibenclamide monotherapy or metformin itself (Chien et al., 2007), (Gumantara and Oktarlina, 2017). The result of the ABCC8 genotypes and their therapeutic outcomes in a mutant homozygote (TT); showed a controlled 2-hour postprandial blood glucose of $75 \%$, for FBG of $25 \%$ is controlled, while for $\mathrm{HbA} 1 \mathrm{c} 100 \%$ is not controlled. Patients with mutant heterozygote genotypes (CT) showed 2-hour postprandial blood glucose and FBG 100\% controlled and HbA1c 33.3\% controlled. While wildtype (CC) showed 2-hour postprandial blood glucose and FBG 33.3\% controlled and HbA1c 100\% uncontrolled (Table 3).

Table 3. $A B C C 8$ gene genotypes and patient therapy outcomes

\begin{tabular}{llccc}
\hline & & \multicolumn{2}{c}{ Genotype } & Total \\
\cline { 3 - 5 } & & $\begin{array}{c}\text { Wild-type } \\
\text { (CC) }\end{array}$ & $\begin{array}{c}\text { Mutations } \\
\text { (CT+TT) }\end{array}$ & \\
\cline { 3 - 5 } 2-hour & Controlled & $1(10 \%)$ & $6(60 \%)$ & $10(100 \%)$ \\
$\begin{array}{l}\text { postprandial } \\
\text { blood }\end{array}$ & Uncontrolled & $2(20 \%)$ & $1(10 \%)$ & \\
glucose & & & & \\
FBG & Controlled & $1(10 \%)$ & $4(40 \%)$ & $10(100 \%)$ \\
& Uncontrolled & $2(20 \%)$ & $3(30 \%)$ & \\
HbAlc & Controlled & 0 & $1(10 \%)$ & $10(100 \%)$ \\
& Uncontrolled & $3(30 \%)$ & $6(60 \%)$ & \\
\hline
\end{tabular}

Notes: FBG: Fasting Blood Glucose, HbA1C Hemoglobin A1c.

The limitations of this study are the smaller number of patients. Patients who using sulfonylurea monotherapy are minimal, mainly using the combination of therapy with biguanide. Furthermore, it is necessary to measure blood glucose levels and HbAlc more than once to obtain more accurate therapeutic outcome data. Further studies with many participants are needed to clearly explain the association between $A B C C 8$ gene polymorphism and susceptibility of diabetes mellitus or response to treatment.

\section{CONCLUSION}

There is a point mutation in the $A B C C 8$ gene in the Solo population with a wild-type genotype of $30 \%$, a mutant homozygote of $40 \%$, and a mutant heterozygote of $30 \%$. Analysis of genotypes and their therapeutic outcomes in a mutant homozygote (TT) showed a controlled 2-hour postprandial blood glucose of $75 \%$, for FBG of $25 \%$ steady, while HbA1c $100 \%$ is not controlled. Mutant heterozygote genotypes (CT) showed 2-hour postprandial blood glucose and FBG 100\% owned and HbA1c 33.3\% owned. While wild-type (CC) represent 2-hour postprandial blood glucose and FBG $33.3 \%$ controlled and $\mathrm{HbA} 1 \mathrm{c} 100 \%$ uncontrolled.

\section{ACKNOWLEDGEMENT}

A big thanks to Moewardi Hospital Surakarta, especially the clinical Pathology Laboratory, which helped in the sampling process. A big thanks are also given to the Institute for Research, and Community Service of Ahmad Dahlan University (LPPM UAD), Ahmad Dahlan University and Laboratory of Biological Research campus IV, Ahmad Dahlan University Yogyakarta for facilitating 
this research. Moreover, the author also wanted to thank all respondents for their willingness to participate in the study.

\section{REFERENCES}

ADA. (2020). Standars of medical care in diabetes 2020 ADA. American Diabetes Association, 43(479), 960 - 1010. https://doi.org/10.1192/bjp.111.479.1009-a

Al Mansour, M. A. (2020). The prevalence and risk factors of type 2 diabetes mellitus (DMT2) in a semi-urban Saudi population. International Journal of Environmental Research and Public Health, 17(1), 1 - 8. https://doi.org/10.3390/ijerph17010007

Anonim. (2021). ABCC8 Gene. https://www.genecards.org/cgi-bin/carddisp.pl?gene=ABCC8\%0A25 maret 2021; $9.38 \mathrm{pm}$

Begic, E., Arnautovic, A., \& Masic, and. (2016). Assessment of Risk Factors for Diabetes Mellitus Type 2. Materia Socio Medica, 28(3), 187. https://doi.org/10.5455/msm.2016.28.187-190

Chien, H. H., Chang, C. T., Chu, N. F., Hsieh, S. H., Huang, Y. Y., Lee, I. Te, Lee, W. J., Tang, Y. J., \& Sheu, W. H. H. (2007). Effect of glyburide-metformin combination tablet in patients with type 2 diabetes. Journal of the Chinese Medical Association, 70(11), 473 - 480. https://doi.org/10.1016/S1726-4901(08)70044-3

Engwa, G. A., Nwalo, F. N., Chikezie, C. C., Onyia, C. O., Ojo, O. O., Mbacham, W. F., \& Ubi, B. E. (2018). Possible association between ABCC8 C49620T polymorphism and type 2 diabetes in a Nigerian population. BMC Medical Genetics, 19(1), 1 - 7. https://doi.org/10.1186/s12881-0180601-1

Firdaushty, R., Usman, E., \& Linosefa, L. (2020). Gambaran polimorfisme gen SLC22A1 rs683369 pada pasien diabetes melitus tipe 2 yang mendapatkan terapi metformin. Jurnal Kesehatan Andalas, 9(1S), 88 - 93. https://doi.org/10.25077/jka.v9i1s.1160

Gumantara, M. P. B., \& Oktarlina, R. Z. (2017). Perbandingan monoterapi dan kombinasi terapi sulfonilurea-metformin terhadap pasien diabetes melitus tipe 2. Majority, 6(1), 1 - 5

Haghverdizadeh, P., Sadat Haerian, M., Haghverdizadeh, P., \& Sadat Haerian, B. (2014). ABCC8 genetic variants and risk of diabetes mellitus. Gene, 545(2), 198 - 204. https://doi.org/10.1016/j.gene.2014.04.040

Hu, M., Wan, Y., Yu, L., Yuan, J., Ma, Y., Hou, B., Jiang, X., \& Shang, L. (2017). Prevalence, awareness and associated risk factors of diabetes among adults in Xi' an, China. Scientific Reports, 7(1), 1 - 9. https://doi.org/10.1038/s41598-017-10797-x

Januaristiningtyas, A. I. (2018). Trend dan prevalensi diabetes mellitus tipe 2 di kota Surakarta. Diabetic Research, 121

Kemenkes. (2018). Hari diabetes sedunia tahun 2018 definisi diabetes

Kemenkes RI. (2018). Laporan provinsi Jawa Tengah Riskesdas 2018. In Kementerian Kesehatan RI

Klen, J., Dolžan, V., \& Janež, A. (2014). CYP2C9, KCNJ11 and ABCC8 polymorphisms and the response to sulphonylurea treatment in type 2 diabetes patients. European Journal of Clinical Pharmacology, 70(4), 421 - 428. https://doi.org/10.1007/s00228-014-1641-x

Koren, S., \& Koren, R. (2015). Any Polymorphisms of CYP2C9 Affects the Biochemical Profile of Diabetic Patients Receiving Glibenclamide. Clinical \& Medical Biochemistry: Open Access, 01(01), 1 - 4. https://doi.org/10.4172/2471-2663.1000102

Ordelheide, A. M., Hrab ě De Angelis, M., Häring, H. U., \& Staiger, H. (2018). Pharmacogenetics of oral antidiabetic therapy. Pharmacogenomics, 19(6), 577 - 587. https://doi.org/10.2217/pgs2017-0195

Qin, L. J., Lv, Y., \& Huang, Q. Y. (2013). Meta-analysis of association of common variants in the KCNJ11-ABCC8 region with type 2 diabetes. Genetics and Molecular Research, 12(3), 2990 3002. https://doi.org/10.4238/2013.August.20.1

Riskesdas, K. (2018). Hasil utama riset kesehatan dasar (RISKESDAS). Journal of Physics A: 
Mathematical and Theoretical, 44(8), 1 - 200. https://doi.org/10.1088/1751-8113/44/8/085201

Sakamoto, Y., Inoue, H., Keshavarz, P., Miyawaki, K., Yamaguchi, Y., Moritani, M., Kunika, K., Nakamura, N., Yoshikawa, T., Yasui, N., Shiota, H., Tanahashi, T., \& Itakura, M. (2007). SNPs in the KCNJ11-ABCC8 gene locus are associated with type 2 diabetes and blood pressure levels in the Japanese population. Journal of Human Genetics, 52(10), 781 - 793. https://doi.org/10.1007/s10038-007-0190-x

Venkatesan, R., Bodhini, D., Narayani, N., \& Mohan, V. (2014). Association study of the ABCC8 gene variants with type 2 diabetes in south Indians. Indian Journal of Human Genetics, 20(1), 37 - 42. https://doi.org/10.4103/0971-6866.132752

Wiyatno, A., Artika, I. M., \& Malik, S. G. (2011). Asosiasi polimorfisme gen kcnj11 dan abcc8 dengan diabetes mellitus tipe 2 pada populasi masyarakat bali ageng wiyatno. Pharmacogenetic Research

Yokoi, N., Kanamori, M., Horikawa, Y., Takeda, J., Sanke, T., Furuta, H., Nanjo, K., Mori, H., Kasuga, M., Hara, K., Kadowaki, T., Tanizawa, Y., Oka, Y., Iwami, Y., Ohgawara, H., Yamada, Y., Seino, Y., Yano, H., Cox, N. J., \& Seino, S. (2006). Association studies of variants in the genes involved in pancreatic $\beta$-cell function in type 2 diabetes in Japanese subjects. Diabetes, 55(8), 2379 - 2386. https://doi.org/10.2337/db05-1203

Zhou, D., Zhang, D., Liu, Y., Zhao, T., Chen, Z., Liu, Z., Yu, L., Zhang, Z., Xu, H., \& He, L. (2009). The E23K variation in the KCNJ11 gene is associated with type 2 diabetes in Chinese and East Asian population. Journal of Human Genetics, 54(7), 433 - 435. https://doi.org/10.1038/jhg.2009.54

Zhou, X., Chen, C., Yin, D., Zhao, F., Bao, Z., Zhao, Y., Wang, X., Li, W., Wang, T., Jin, Y., Lv, D., Lu, Q., \& Yin, X. (2019). A variation in the ABCC8 gene is associated with type 2 diabetes mellitus and repaglinide efficacy in chinese type 2 diabetes mellitus patients. Internal Medicine, 58(16), 2341 - 2347. https://doi.org/10.2169/internalmedicine.2133-18 